\title{
Impact of Genotoxic Contaminants on DNA Integrity of Copepod from Freshwater Bodies in Chennai, Tamil Nadu, India
}

\author{
Gomathi Jeyam M and Ramanibai $\mathbf{R}^{*}$
}

Department of Zoology, University of Madras, Guindy Campus, Chennai-25, India

\begin{abstract}
In the present study, we evaluated the DNA damage of freshwater copepod Mesocyclops aspericornis collected from Chembarambakkam, Velachery and Retteri Lake during Premonsoon(PRM) and Post-monsoon (POM) by alkaline comet assay. The highest DNA integrity was observed at Velachery Lake (21.52 \pm 0.31 Mean \% Tail DNA) followed by Retteri Lake (13.84 \pm 0.019 Mean \% Tail DNA) during both season, whereas the lowest DNA integrity occurred at Chembarambakkam $(0.16 \pm 0.14$ Mean \% Tail) and identified as the reference site. The single cell gel electrophoresis of $M$. aspericornis clearly showed relatively higher olive tail moment from the contaminated sites Velachery and Retteri Lake $(4.66 \pm 0.055 ; 1.42 \pm 0.12)$. During study period we observed the lowest $\mathrm{pH}$ and dissolved oxygen levels in the contaminated sites than the reference site. Moreover high level of genotoxic contaminants especially heavy metals $(\mathrm{Zn}, \mathrm{Cr}, \mathrm{Mn}, \mathrm{Pd}, \mathrm{Ni}, \mathrm{Cu}, \mathrm{Co})$ are widespread in all sites, which could be mainly attributed to the high integrity of DNA in freshwater copepod. The results obtained in this study provide an early warning signal of contamination of the freshwater bodies of Chennai by genotoxic contaminants and explore the importance to conservation of those water bodies.
\end{abstract}

Keywords: Mesocyclops aspericornis; Heavy metal; Physicochemical parameters; DNA damage

\section{Introduction}

Nowadays, water pollution is a worldwide issue due to the increasing input of genotoxic agents into aquatic environment and water pollution has currently focused on notice on the evaluation of the cause of genotoxic agents to organisms and ecosystems [1].

Currently, aquaculture has become a raising vital part of the world economy. Copepods play most important roles in pond ecosystems, serving as food for small fish, Micropredators of fish and other organisms, Fish parasites, Intermediate hosts of fish parasites, hosts and vectors of human diseases. Copepods of the order Cyclopoida are the major food items in freshwater aquaculture and copepod nauplii are particularly valuable for feeding fry. Copepods used as natural food are either cultured or collected from natural water bodies. Adult copepodid stages of cyclopoids are predators to control the Mosquito larvae. Finally, copepods serve as intermediate hosts for parasites that infect humans and can serve as vectors of serious human diseases like cholera [2,3].

The first step in monitoring the water quality has a high priority for the determination of current conditions and long term trends in effective management. Though, alertness and alarm thresholds of these parameters only concern the toxic things of the polluting substances studied and do not take into thought the question of chronic exposure at low doses of noxious chemicals, commonly present in complex mixtures [3].

The environment affected by the metals is of particular concern, due to the anthropogenic activities [4]. In recent years, heavy metal pollution accumulated in water bodies has fascinated the attention of the scientific community not only from the perspective of public health as related to water supplies, but also for the damage caused to aquatic life. These heavy metals are introduced in the aquatic system from both natural and anthropogenic sources. The contamination of copepods by heavy metals can much affect other freshwater organisms or even human beings through food chains accumulation and transfer [5].

Genetic approaches suggest powerful tools to investigate the modern status of populations, deduce the history of population changes and expecting future population direction [6] on living organisms, which have a response to genotoxicants, DNA damage due to genotoxicants experience in aquatic environment, can be used as a biological indicators or biomarkers [7]. They suggest the opportunity of genotoxicant assessment into aquatic environment and currently using them to evaluate ecosystem or organism health is a popular concept [8]. Even though, DNA damages as biomarkers do not disclose specific response of genotoxicants; at rest it is useful on the ecotoxicological measurement since it help as an early warning system [9] that determines the bioavailability and the effect of genotoxicants. At present, there is much attention in resolute the level of DNA strand breakage (SB) as a perceptive indicator of genotoxicity [10].

The aim of the present study was to estimate the DNA integrity in Freshwater copepod collected from three sites: two lakes being partially polluted with metals due to anthropogenic activities (Velachery Lake and Retteri Lake) and the other less polluted freshwater was used as a reference site (Chembarambakkam Lake). The above three lakes are an important freshwater bodies of Chennai. The water of the lakes used for drinking, irrigation and aquaculture practices. In order to understand the effect of seasonal variation, sampling was conducted during Premonsoon (PRM), and Post-monsoon (POM) of the year of 2016. The results give baseline information for overall management of the water bodies, which very much influenced the life and socioeconomic disaster especially to the local population. The work is useful to know the causes of various sources, which influence the quality of water.

\section{Materials and Methods}

\section{Metal analysis in water and plankton}

Samples were collected during Premonsoon and Postmonsoon of

*Corresponding author: Ramanibai R, Department of Zoology, University of Madras, Guindy Campus, Chennai-25, India, Tel: +9444020828; E-mail: rramani8@hotmail.com

Received April 07, 2017; Accepted April 22, 2017; Published May 04, 2017

Citation: Jeyam MG, Ramanibai R (2017) Impact of Genotoxic Contaminants on DNA Integrity of Copepod from Freshwater Bodies in Chennai, Tamil Nadu, India. J Environ Anal Toxicol 7: 464. doi: 10.4172/2161-0525.1000464

Copyright: () 2017 Jeyam MG, et al. This is an open-access article distributed under the terms of the Creative Commons Attribution License, which permits unrestricted use, distribution, and reproduction in any medium, provided the original author and source are credited. 
Citation: Jeyam MG, Ramanibai R (2017) Impact of Genotoxic Contaminants on DNA Integrity of Copepod from Freshwater Bodies in Chennai, Tamil Nadu, India. J Environ Anal Toxicol 7: 464. doi: 10.4172/2161-0525.1000464

Page 2 of 5

2016. The locations selected for the investigation were from Chennai at sampling points of area names as shown in Figure 1. Before the collection of samples, each bottle was first rinsed with sample for preconcentration. Heavy metals in water and plankton were extracted with conc. HNO3 and preserved in a refrigerator till analysis for $\mathrm{Cr}, \mathrm{Ni}$, $\mathrm{Co} \mathrm{Zn}, \mathrm{Mn}, \mathrm{Pb}, \mathrm{Cu}$, and $\mathrm{Fe}$ [11]. The samples were analysed for these selected heavy metals through atomic absorption spectrophotometer. Determination of Copepod was done (Figure 2) [12,13].

\section{Water chemistry}

The Physico chemical properties at both sampling sites were assessed using standard methods [14]. Water temperature and $\mathrm{pH}$ was measured in site using Mercury Thermometer and $\mathrm{pH}$ Meter. Other parameter like Dissolved Oxygen was measured in the laboratory.

\section{The alkaline comet assay}

To know the species variability in DNA damage, the copepod $M$. aspericornis was selected as they are the most abundant species available at all three sites during each sampling season. All the copepod samples for comet assay were brought to the laboratory immediately after collection in ambient water with calm aeration. The target copepod species were sorted under a stereo zoom microscope and processed additional for comet assay. At least 100 copepods of each species were washed with double distilled water (in order to remove bacteria, protozoa and algae), collected in Eppendorf tubes and weighed. Suspension of cells was prepared by crushing the animals using a Teflon mini homogenizer for

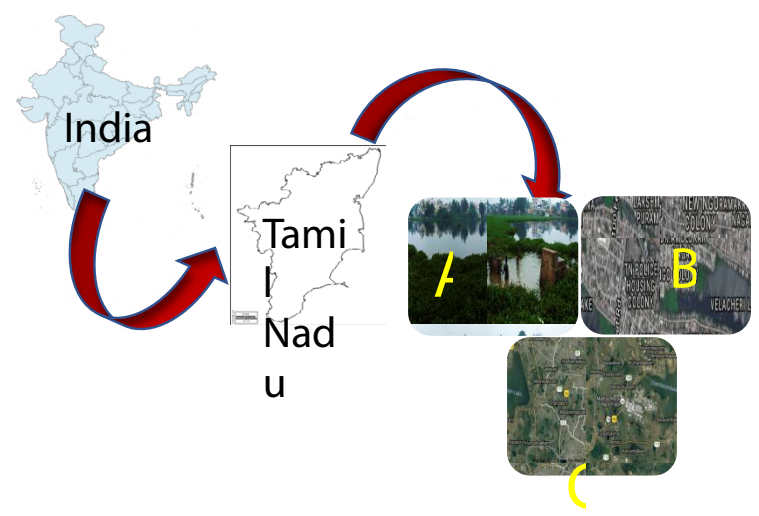

Figure 1: Images showing different sampling locations of study area (A) Chembarambakkam Lake (B) Velachery Lake (C) Retteri Lake.

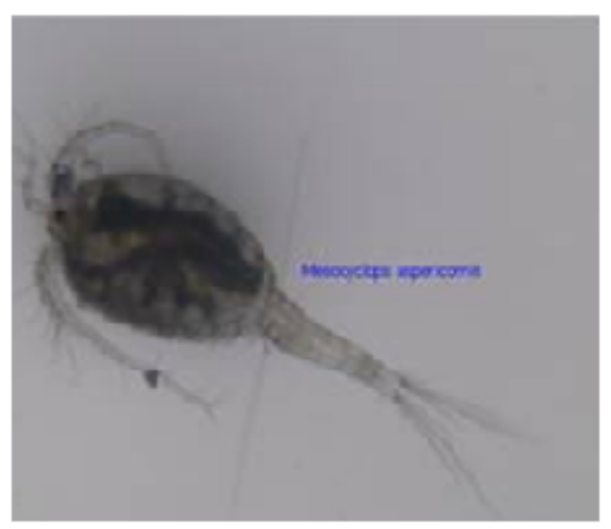

Figure 2: Images showing Copepod (Mesocyclops aspericornis). mechanical disintegration. A suspension of cells was obtained and the viability of the cells was checked routinely using trypan blue reagent (100 cells were counted per sample). Cell suspensions were immediately processed for the alkaline comet assay. The comet assay was performed according to [6] with slight modification. All preparatory steps were performed under dim light to avoid additional DNA damage. For each sample, three slides were arranged and observed under Nikon E200 epi-fluorescence microscope (magnification 400X) with an excitation filter of 510-560 nm. Comets were accidentally captured at the same depth of the gel. The edges of the gel, rare dead cells, cells near or in an attentive air bubble and superimposed comets were avoided. Images of 100 selected cells ( 30 cells from each slide) were analyzed for each sample. Cells were categorized for grade of damage (using \% of tail DNA) based on the criteria grade of damage was categorized as: zero to minimal $<5 \%$, low damage $<5-20 \%$, moderate damage $<20-40 \%$, high damage $<40-75 \%$ and extreme damage $<75-100 \%$.

\section{Statistical analysis}

All data are presented as means $\pm \mathrm{SD}$. The parameters chosen for the quantification of DNA damage were: mean \% Head DNA, mean \% Tail DNA and Olive tail moment as calculated by the CASP software.

\section{Results}

\section{Metal analysis in water}

Metals enter the aquatic environment through erosion of the geological matrix, or due to various anthropogenic activities that are caused by industrial effluents, domestic sewage, and mining wastes. The concentrations of dissolved heavy metals in the water samples from each lake between different seasons are shown in Figures 3 and 4. The mean concentrations of the measured metals in water was found to be in the following sequence; $\mathrm{Zn}>\mathrm{Cr}>\mathrm{Mn}>\mathrm{Pb}>\mathrm{Cu}>\mathrm{Fe}>\mathrm{Ni}>\mathrm{Co}$. All the metals attained their maximum levels at Lake Velachery followed by Retteri and Chembarambakkam Lake was received least values.

The highest concentrations of Zinc were observed in the Velachery and Retteri Lake $(0.28 \pm 0.02$ and $0.25 \pm 0.01 \mathrm{mg} / \mathrm{L})$ during POM when compared to the Reference site Chembarambakkam Lake $(0.06 \pm 0.0$ $\mathrm{mg} / \mathrm{L}$ ). The concentration of chromium showed $0.26 \pm 0.03$ and 0.25 $\pm 0.02 \mathrm{mg} / \mathrm{L}$ respectively on Velachery and Retteri Lake, which was relatively higher than the reference site $(0.01 \pm 0.01 \mathrm{mg} / \mathrm{L})$. Similarly, we have observed the high concentration of other metals such as $\mathrm{Mn}, \mathrm{Pb}$, $\mathrm{Cu}, \mathrm{Fe}, \mathrm{Ni}, \mathrm{Co}$ in the series of Velachery $>$ Retteri $>$ Chembarambakkam.

\section{Metal analysis in Plankton}

The metal concentrations in Plankton are closely associated with metal content of water in the three Lakes and detected in the following order: $\mathrm{Zn}>\mathrm{Cr}>\mathrm{Mn}>\mathrm{Pb}>\mathrm{Cu}>\mathrm{Fe}>\mathrm{Ni}>\mathrm{Co}$. This may be attributed to the abundance of these metals in water by the same pattern. The mean concentration of $\mathrm{Zn}, \mathrm{Cr}$ and $\mathrm{Mn}(2.66 \pm 0.01,1.16 \pm 0.12,0.93 \pm 0.03$ $\mathrm{mg} / \mathrm{g}$,) are higher at Velachery Lake and Retteri Lake $(1.75 \pm 0.02,0.65$ $\pm 0.01,0.56 \pm 0.02 \mathrm{mg} / \mathrm{g}$ ) during the POM samples. Likewise, maximum concentration of all other metals is recorded in Velachery and Retteri lake than Chembarambakkam lake during POM and PRM season 2016 (Figures 5 and 6).

\section{Physico chemical characteristics}

The variations of Physico chemical parameters in the surface water ( $\mathrm{pH}, \mathrm{DO}$ and Temperature) from each sampling sites during the two seasons are reproduced in the Table 1 . The Highest temperature was observed at (avg. $\left.32^{\circ} \mathrm{C}\right)$ followed by Retteri $\left(\right.$ avg. $\left.30^{\circ} \mathrm{C}\right)$ and Velachery 
Citation: Jeyam MG, Ramanibai R (2017) Impact of Genotoxic Contaminants on DNA Integrity of Copepod from Freshwater Bodies in Chennai, Tamil Nadu, India. J Environ Anal Toxicol 7: 464. doi: 10.4172/2161-0525.1000464

Page 3 of 5

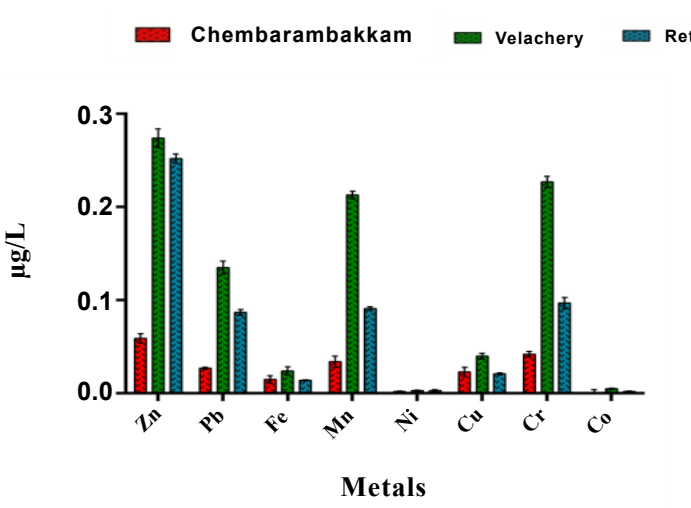

Figure 3: Distribution of Heavy metals in surface water during Premonsoon 2016 at various sampling sites. All the results represented as mean $\pm \mathrm{SD}$.

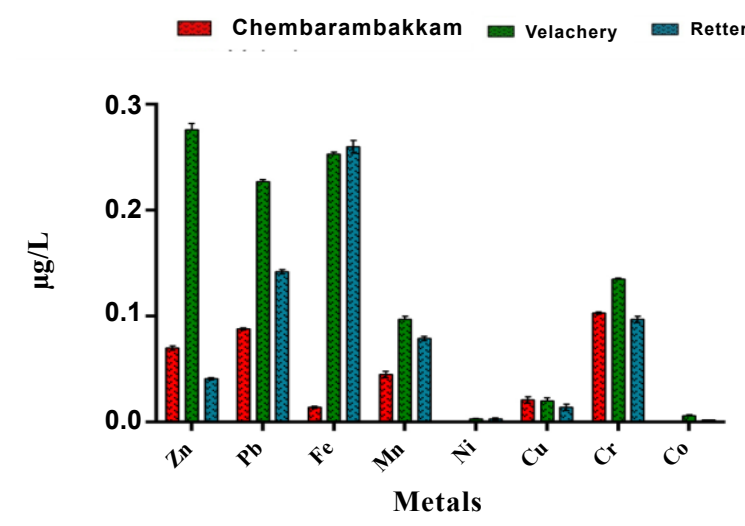

Figure 4: Distribution of Heavy metals in surface water during Postmonsoon 2016 at various sampling sites. All the results represented as mean $\pm \mathrm{SD}$.

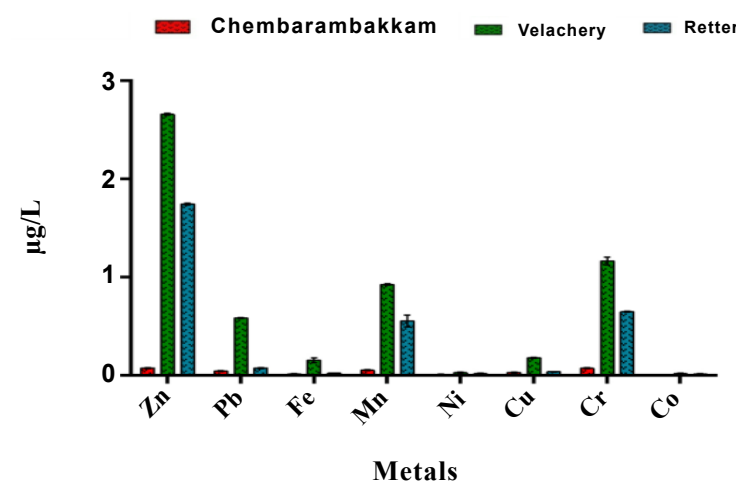

Figure 5: Distribution of Heavy metals in copepod (M. aspericornis) at various sampling sites during premonsoon 2016. All the results represented as mean \pm SD.

(avg. $29^{\circ} \mathrm{C}$ ) during Pre monsoon. The same trend was observed during Post monsoon itself. The $\mathrm{pH}$ of different lakes ranged between 7.3 to 8.1. The low $\mathrm{pH}$ was noticed in Velachery (7.3) and Retteri (7.5) than the Chembarambakkam Lake (8.1) during both seasons. The range of DO was varied from 4.03 to $6.36 \mathrm{mg} / \mathrm{L}$. The high level of DO was observed at Retteri followed by Velachery and Chembarambakkam.

\section{The alkaline comet assay}

The DNA integrity of freshwater copepod was evaluated by alkaline comet assay. The results shown in Table 2 clearly illustrated that the extend of DNA damage in freshwater copepod in terms of variation in different parameters such as Mean \% head, Mean \% Tail and Mean Olive Tail moment of the comets of the cells from various sampling sites during the PRM and POM seasons 2016.

High level of DNA integrity was observed from the samples of Velachery and Retteri Lake during both season, where as the most striking point of observation was found in POM season at Velachery lake $(21.52 \pm 0.31 \%$ Tail DNA) and Retteri lake (13.84 $\pm 0.019 \%$ Tail DNA). Interestingly DNA integrity in $M$. aspericornis was found to be relatively quite low at Chembarambakkam Lake $(0.35 \pm 0.31 \%$ Tail DNA) during the study period.

\section{Discussion}

Genotoxic pollutants in the freshwater environment are mounting at disturbing rate, thereby stressing the need for rapid and accurate monitoring of genotoxicity in aquatic organisms. Known that copepod is a biomarker against genotoxic contaminants because they act as primary consumers in freshwater ecosystems and it is vulnerable to various environmental contaminants by uptake from the dissolved phase as well as from food sources [15] only a few studies have been carried out on impact of genotoxic contaminants in freshwater zooplankton [6]. The present study provides preliminary data of DNA integrity in Freshwater copepods (M. aspericornis) that are affected by varying water quality parameter particularly heavy metal.

In our results, high concentration of all the metals was observed at Velachery and Retteri Lake than the reference site. The important reason behind that, this region receiving enormous quantities of sewage waste from nearby areas. Chembarambakkam Lake appeared to be the cleanest because this region away from the cities and did not receives any pollutants. The highest level of metals in the water was found during POM, while the lowest values occurred during PRM. These seasonal variations may be due to the fluctuation of the amount of agricultural drainage water and sewage effluents discharged into the lake [16].

The concentration of $\mathrm{Cr}, \mathrm{Mn}$ and $\mathrm{Zn}$ are higher during post monsoon at both surface water and Planktons at all the sampling sites. The high concentration of these metals in the surface water and Planktons may have unfavorable impact to the slum population living nearby as they

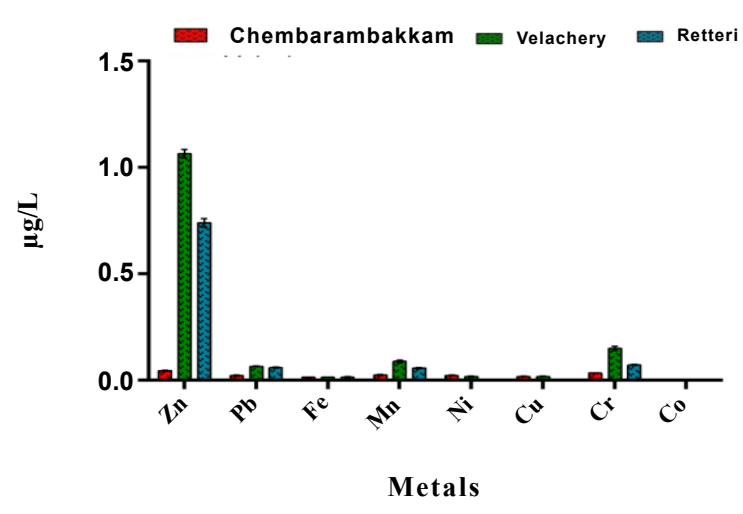

Figure 6: Distribution of Heavy metals in copepod M. aspericornis at various sampling sites during Postmonsoon 2016. All the results represented as mean \pm SD. 
Citation: Jeyam MG, Ramanibai R (2017) Impact of Genotoxic Contaminants on DNA Integrity of Copepod from Freshwater Bodies in Chennai, Tamil Nadu, India. J Environ Anal Toxicol 7: 464. doi: 10.4172/2161-0525.1000464

Page 4 of 5

\begin{tabular}{|c|c|c|c|c|c|c|}
\hline \multirow[b]{2}{*}{ Parameters } & \multicolumn{2}{|c|}{ Chembarambakkam } & \multirow{2}{*}{$\begin{array}{r}\text { Velachery } \\
\text { Premonsoon }\end{array}$} & \multirow[b]{2}{*}{ Postmonsoon } & \multicolumn{2}{|c|}{ Retteri } \\
\hline & Premonsoon & Postmonsoon & & & Premonsoon & Postmonsoon \\
\hline Temperature $\left({ }^{\circ} \mathrm{C}\right)$ & $32^{\circ} \mathrm{C}$ & $29^{\circ} \mathrm{C}$ & $29^{\circ} \mathrm{C}$ & $26^{\circ} \mathrm{C}$ & $30^{\circ} \mathrm{C}$ & $27^{\circ} \mathrm{C}$ \\
\hline pH & 8.1 & 8.1 & 7.4 & 7.3 & 7.5 & 7.5 \\
\hline Dissolved Oxygen (mg/L) & 4.03 & 4.03 & 4.05 & 6.25 & 4.06 & 6.36 \\
\hline
\end{tabular}

Table 1: Variation of physico-chemical characteristics in the freshwater bodies at different season.

\begin{tabular}{|c|c|c|c|c|c|}
\hline & \multicolumn{2}{|c|}{ Chembarambakkam } & Velachery & Retteri \\
\hline Parameters & Premonsoon & Postmonsoon & Premonsoon & Postmonsoon & Premonsoon \\
\hline Mean\% Head DNA & $99.83 \pm 0.14$ & $99.88 \pm 0.13$ & $81.27 \pm 0.27$ & $78.47 \pm 0.31$ & $89.27 \pm 0.15$ \\
\hline Mean\% Tail DNA & $0.16 \pm 0.14$ & $0.35 \pm 0.31$ & $18.92 \pm 0.06$ & $21.52 \pm 0.31$ & $10.48 \pm 0.23$ \\
\hline Olive Tail Movement & $0.05 \pm 0.05$ & $0.03 \pm 0.05$ & $6.21 \pm 0.21$ & $4.66 \pm 0.06$ & $0.60 \pm 0.01$ \\
\hline
\end{tabular}

Table 2: Alkaline comet assay on Copepod (M. aspericornis) collected in the Lake Velachery, Retteri and Chembarambakkam Lake during pre and post monsoon seasons. All the results represented as mean \pm SD.

are using this water for bathing and laundry (Environment Agency). $\mathrm{Zn}$ is present in large amount in natural water and next to Fe in terms of concentrations in this study. Zn level is evocative of the influence of refuse dump and domestic sewage sources. This suggests the strong anthropogenic influence due to urbanization within the catchments of waterbodies of Chennai. Kahle and Zauke [17] who reported that high level of chromium and copper pollutions has the main reason for the loss of aquatic biota in the river of "Fez and Sebou" in the region of Fez (Morocco).

$\mathrm{Fe}$ is an important metal in both plants and animals particularly in the cellular process [18]. The insoluble $\mathrm{Fe}^{3+}$ is reduced to soluble $\mathrm{Fe}^{2+}$ in water by bacterial reduction. $\mathrm{Fe}$ is found in natural fresh and groundwater, but have no health based guideline value. Concentration of the $\mathrm{Fe}$ of studied water samples ranging from $0.01 \pm 0.05$ to 0.02 \pm 0.04 According to Koukal et al. [19] we have noticed minimum concentration of $\mathrm{Fe}$ at all sampling sites. $\mathrm{Pb}$ is potentially dangerous to life in different forms owing to toxicity [20]. According to WHO [21] the standard value of $\mathrm{Pb}$ is $0.05 \mathrm{mg} / \mathrm{L}$ in the aquatic environment. In our study, we have observed the high concentration of $\mathrm{Pb}$ values than the BIS standard at Velachery (Both seasons) and Retteri lake than reference site (Chembarambakkam Lake). Although high concentrations give rise to consumer complaints due to its ability to discolor aerobic waters at concentration above $0.05 \mathrm{mg} / \mathrm{L}$ [22] Problems survive however in areas with soft slightly alkaline water which may dissolve lead from the lead pipes; plastic pipes in which lead has been used as a stabilizer [19] which is the reason may be attributed to increase the lead concentration in Velachery Lake. The level of $\mathrm{Cu}$ was in excess amount it becomes toxic for aquatic life as well as human beings. According to BIS [23] Standard threshold value of $\mathrm{Cu}$ is 0.05 $\mathrm{mg} / \mathrm{L}$. In a study $\mathrm{Cu}$ content was found above the desirable limit in reference site (Chembarambakkam) and higher in other sampling sites, which was probably owing to domestic sewage waste and land run off.

High concentration of $\mathrm{Ni}$ was observed in Retteri and Velachery Lake than the reference site, which may be due to the pollution by motor parts waste, sewage waste and domestic waste at this station. The highest level of Ni in PRM season might be due to the evaporation effect of water. Ni concentration was above the desirable limit given by BIS [23]. The Concentration of all the metals is higher in plankton from both seasons. The result was similar to that reported by Yayintas et al. [24]. In the present study, abiotic parameters such as temperature, $\mathrm{pH}$ and dissolved oxygen were observed very low at Retteri and Velachery Lake. The low $\mathrm{pH}$ and then consider as dangerous to health. The water has the capacity of mineral acids, which dissolve the metals and toxic in nature. Lower levels of salinity and dissolve oxygen can strengthen environmental stress and may amplify the contamination effect, thus contributing to an increase in DNA damage [25].
The extent of DNA damage was evaluated in terms of the levels of DNA integrity in Freshwater copepod at various sampling sites. During Postmonsoon season significant impairment of DNA integrity was detected at Velachery Lake and moderate impairment of DNA integrity at Retteri Lake whereas the no DNA integrity in the samples collected from Chembarambakkam Lake. The results indicating the persistence of genotoxic contaminants in this aquatic environment. Seasonally, the highest levels of DNA damage were observed during POM, which was associated with higher concentrations of $\mathrm{Zn}, \mathrm{Cr}, \mathrm{Mn}$ and $\mathrm{Pb}$ metals in particulate matter. The comet assay study indicated the potential of $\mathrm{Cr}$, when present in excess concentrations induce DNA damage in the cells of copepod organisms. This result was confirmed with Plankton as an Indicator of heavy Metal Pollution in a Freshwater Reservoir [6]. In previous study the Comet assay has been used to investigate the levels of DNA damage in marine and freshwater copepods exposed to different water borne pollutants [6,26]. According to Kumarave et al. [27] DNA damage was minimal to moderate $(<40 \%)$ in Chembarambakkam species and minimal to high $(<86 \%)$ from species and the results suggested that the Retteri and Velacheri lake are contaminated with different types of genotoxicants.

\section{Conclusion}

Comet assay is a novel biological analysis, which is a sensitive, flexible, simple, rapid, and inexpensive method to assess aquatic genotoxicant. Overall, evaluation of these results indicated that the level of DNA damage in freshwater copepod (M. aspericornis) was found to be quite prominent due to their exposure of genotoxic pollutants. In terms of the loss of DNA integrity provides precious clues for observation of the occurrence of genotoxic contaminants at different locations. The evaluation of the DNA damage in freshwater copepod is of great importance and can be used as biomarker for early detection of environmental carcinogenesis. However, increased anthropogenic activities have increased the possible pollution of the lakes particularly the heavy metal pollutants which may be toxic to humans and aquatic fauna. The heavy metals like $\mathrm{Ni}, \mathrm{Fe}$ and $\mathrm{Cu}$ in water samples of these water bodies are within the BIS and WHO recommended value. The obtained results should be considered for the future advance planning for water management purposes.

\section{References}

1. Shen S, Zhang Y (2016) Heavy Metal Analysis in Tai Lake Water Sample Based on Vanadium Oxide-Polypropylene Carbonate Modified Electrode. Int J Electrochem Sci 11: 5669-5678.

2. Yeole SM, Patil GP (2005) Physico-chemical status of Yedshi Lake in relation to water pollution. J Aquat Biol 20: 41-44. 
Citation: Jeyam MG, Ramanibai R (2017) Impact of Genotoxic Contaminants on DNA Integrity of Copepod from Freshwater Bodies in Chennai, Tamil Nadu, India. J Environ Anal Toxicol 7: 464. doi: 10.4172/2161-0525.1000464

3. Piasecki W, Goodwin AE, Eiras JC, Nowak BF (2004). Importance of Copepoda in Freshwater Aquaculture. Zoo Studies 43: 193-205.

4. Pellacani C, Buschini A, Furlini M, Poli P, Rossi C (2006) A battery of in vivo and in vitro tests useful for genotoxic pollutant detection in surface waters. Aquat Toxicol 77: 1-10.

5. Censi P, Spoto SE, Saiano F, Sprovieri M, Mazzola S, et al. (2006) Heavy metals in coastal water systems. A case study from the northwestern Gulf of Thailand. Chemosphere 64: 1167-1176.

6. Ternjej I Stanković I, Mihaljević Z, Furač L, Želježić D, et al. (2009) Alkaline Comet Assay as a Potential Tool in the Assessment of DNA Integrity in Freshwater Zooplankton Affected by Pollutants from Water Treatment Facility. Water Air Soil Pollut 204: 299-314.

7. Malik N, Biswas AK, Raju CB (2013) Plankton as an Indicator of Heavy Metal Pollution in a Freshwater Reservoir of Madhya Pradesh, India. Bull Environ Contam Toxicol 90: 725-729.

8. Frenzilli G, Nigro M, Lyons BP (2009) The Comet assay for the evaluation of genotoxic impact in aquatic environments. Mutat Res 681: 80-92.

9. Dhawan A, Bajpayee M, Parmar D (2009) Comet assay: a reliable tool for the assessment of DNA damage in different models. Cell Biol Toxicol 25: 5-32.

10. Mitchelmore CL, Chipman JK (1998) DNA strand breakage in aquatic organisms and the potential value of the comet assay in environmental monitoring. Mutat Res 399: 135-147.

11. Ubaidullah M (2003) Studies on heavy metals toxicity of water, sediments, plankton and fish in the River Ravi stretch from Baloki headworks to Sidhnai barrage. Ph. D. Thesis, University of Faisalabad, Pakistan.

12. Battish SK (1992) Freshwater Zooplankton of India. Oxford and IBH Publishing Co. Pvt. Ltd., New Delhi i-iv: 233.

13. Edmondson W (1959) Fresh water biology, Edward And Hipple ( $2^{\text {nd }}$ Edn). John Willy \& Sons Inc, Newyork 95-189

14. APHA (2005) Standard Methods for the Examination of Water and Wastewater (19 ${ }^{\text {th }}$ Edn). American Washington: Public Health association.

15. den Besten PJ, Tuk CW (2000) Relation between responses in the neutral red retention test and the comet assay and life history parameters of Daphnia magna. Mar Environ Res 50: 513-516.
16. Singh NP, Mc Coy MT, Tice RR, Schneider LL (1988) A simple technique for quantitation of low levels of DNA damage in individual cells. Exper. Cell Res 175: $184-191$.

17. Kahle J, Zauke GP (2002) Bioaccumulation of trace metals in the copepod Calanoides acutus from the Weddell Sea (Antarctica): comparison of two compartment and hyperbolic toxicokinetic models. Aquat. Toxicol 59: 115-135.

18. Bahnasawy M, Khidr A, Dheina N (2009) Seasonal Variations of Heavy Metals Concentrations in Mullet, Mugil Cephalus and Liza Ramada (Mugilidae) from Lake Manzal, Egypt. J Appl Sci Res 5: 845-852.

19. Koukal B, Dominik J, Vignati D, Arpagaus P, Santiago S, et al. (2004) Assessment of water quality and toxicity of polluted Rivers Fez and Sebou in the region of Fez (Morocco). Environ Pollut 131: 163-172

20. Joshua N, Edokpayi John O, Odiyo Oluwaseun E, Popoola Titus AM, Msagat (2016) Assessment of Trace Metals Contamination of Surface Water and Sediment: A Case Study of Mvudi River, South Africa. Sustainability 8: 135.

21. Burch MD (2008) Effective doses, guidelines \& regulations. Adv Exp Med Bio 619: 831-853.

22. Fatoki OS, Lujiza N, Ogunfowokan AO (2002) Trace metal pollution in Umtata River. Water Sci Afr 28: 183-189.

23. BIS (1991) Bureau of Indian standard for drinking water. IS: 10500, New Delhi.

24. Yayintas OT, Yilmaz S, Turkoglu M, Colakoglu FA, Cakir F (2007) Seasonal variation of some heavy metal pollution with environmental and microbiological parameters in sub-basin of Kocabas Stream (Biga, Canakkale, Turkey) by ICPAES. Environ Mon Assess 134: 321-331.

25. Mustafa SA, Davies SJ, Jha AN (2012) Determination of hypoxia and dietary copper mediated sub-lethal toxicity in carp, Cyprinus carpio, at different levels of biological organisation. Chemosphere 87: 413-422.

26. Goswami P, Thirunavukkarasu S, Godhantaraman N, Munuswamy N (2014) Monitoring of genotoxicity in marine zooplankton induced by toxic metals in Ennore estuary, Southeast coast of India. Mar Pollut Bull 88: 70-80.

27. Kumaravel TS, Vilhar B, Faux SP, Jha AN (2009) Comet Assay measurements: a perspective. Cell Biol Toxicol 25: 53-64. 